\title{
TRANSFORMING CARE AFTER CONFLICT
}

\section{How gendered care relations are being redefined in northern Uganda}

Lessons from a mixed-methods evaluation of Oxfam's Piloting Gender-Sensitive Livelihoods in Karamoja project

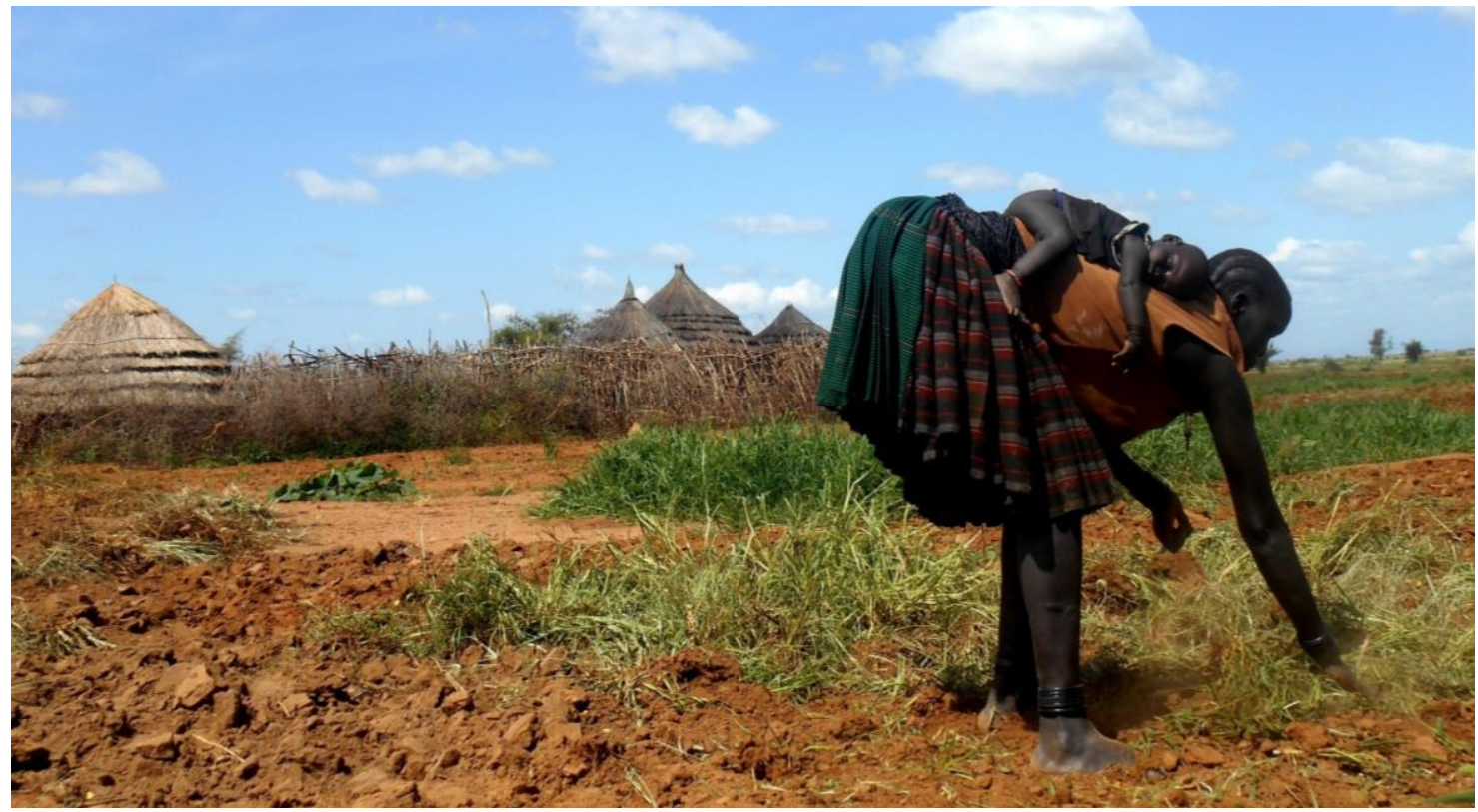

A woman farming while carrying a child on her back, Kotido District, Karamoja.

Photo: Barbara Gärber/University of Vienna, June 2015

ANAM PARVEZ BUTT

RESEARCH TEAM, OXFAM GB

MARTIN WALSH

RESEARCH TEAM, OXFAM GB

BARBARA GÄRBER

PhD CANDIDATE, UNIVERSITY OF VIENNA 


\section{SUMMARY}

Northern Uganda has suffered from chronic food shortages and high levels of poverty, exacerbated in recent decades by severe political insecurity and adverse environmental conditions. Poor women in Karamoja are particularly disadvantaged, constrained by a lack of access to and control over resources, patriarchal exploitation, and harmful social norms. A series of Oxfam interventions has therefore been implemented in this area to support women's livelihoods and promote their socio-economic empowerment and rights. One of these was the Piloting Gender Sensitive Livelihoods in Karamoja (PGSLK) project, implemented in two districts, Kotido and Kaabong, between 2011 and 2014.

The project had two specific work streams: the ending or at least reduction of violence against women and girls (EVAWG), and women's economic empowerment through the provision of support to income generation and livelihoods, using the Gender Action Learning Systems (GALS) approach. A quantitative impact evaluation of the project (hereafter referred to as an 'effectiveness review') found that its economic empowerment activities in Kotido had a positive impact overall, particularly in areas related to women's self-perception, access to resources, involvement in business activities and household wealth. However, the evaluation did not find any positive impact of project activities on the different dimensions of unpaid care work that it measured.

A qualitative follow-up study was commissioned in 2015 to dig deeper into these findings about care work, and, as part of Oxfam's Women's Economic Empowerment and Care initiative (WE-Care), provide a more comprehensive understanding of changing gender and care relations in Kotido and how these have impacted upon and been impacted by the PGSLK project. The results reveal that the project did have an impact on changing men's attitudes towards care work and gendered care relations, but only because it was able to able to build on wider social and economic changes associated with the end of armed conflict in Karamoja and the development of new livelihood strategies that have redefined men's gender roles.

These changes were taking place across Kotido and provided a fertile ground for Oxfam and other agencies' initiatives. This finding underlines the importance of understanding the wider social, political and economic context in which gendered labour relations are continuously negotiated and livelihoods created, and the potential for interventions to take advantage of and sustain positive changes where these are occurring. This is especially pertinent in situations of adversity, where a loss of livelihoods and shifting patterns of mobility due to conflict or climate change may lead to gender norms being redefined, at least temporarily. In such cases, well-designed project interventions can play a critical role in ensuring that such changes endure and become truly transformative. 


\section{CONTENTS}

Summary

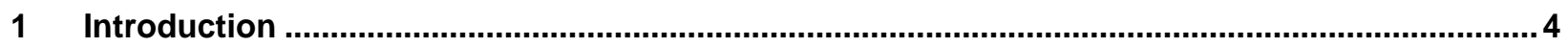

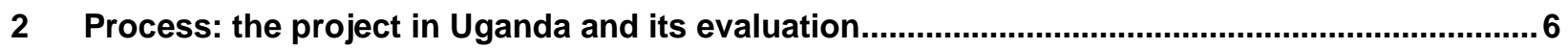

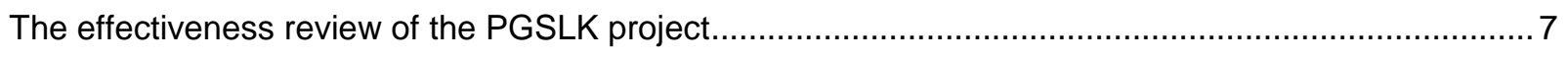

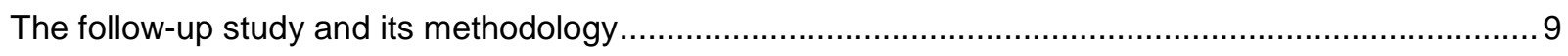

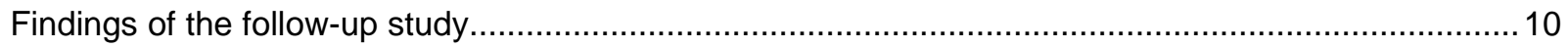

The gendered distribution of care work in Kotido ................................................................... 10

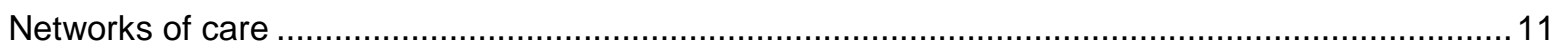

Factors influencing the gendered distribution of care work ....................................................... 12

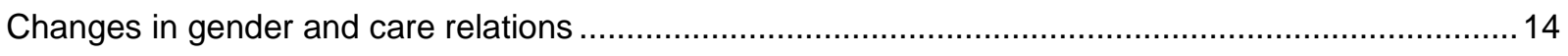

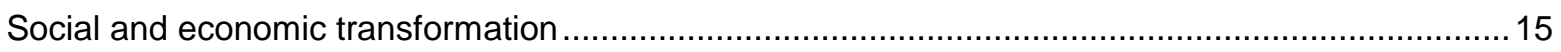

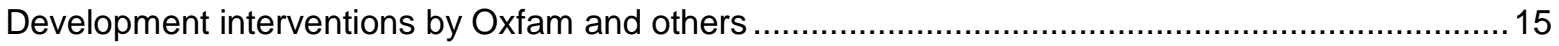

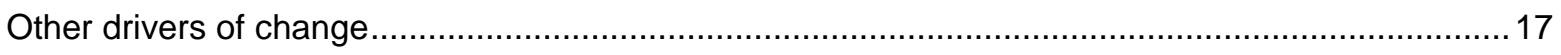

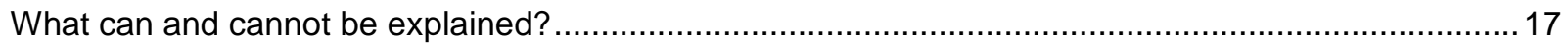

3 Discussion: lessons for programmes and their evaluation ................................................18

Lessons for women's empowerment programmes .................................................................... 18

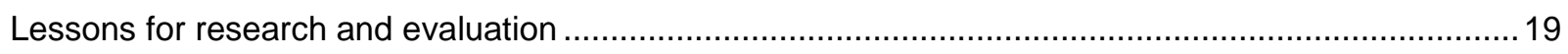

How can the process be improved? ....................................................................................... 19

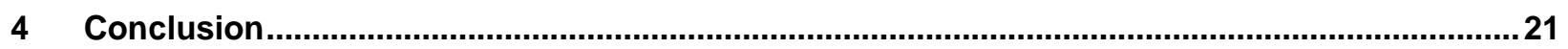

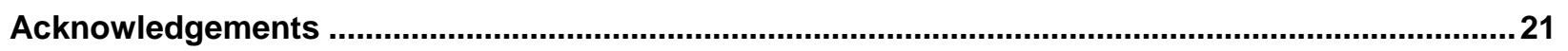

3 Transforming Care after Conflict: How gendered care relations are being redefined in northern Uganda 


\section{INTRODUCTION}

It is widely recognized that one of the most effective ways to improve rural livelihoods is to ensure that women with limited access to and control over productive resources, and suffering from harmful social norms, can exercise their rights and gain power. One of the key challenges to increasing women's socioeconomic empowerment - and a critical pathway to change for livelihoods programmes that Oxfam has identified - is addressing the invisible, heavy, unequal and unpaid care work burden that is predominantly carried out by women.

The term 'unpaid care work' describes the direct care provided to children, the elderly, ill and disabled people at the household and community level; as well as domestic work such as cooking, cleaning, washing and fetching water or firewood that facilitates this direct care. It is unpaid because it emerges out of societal or contractual obligations, and it is work because engaging in it has associated costs in terms of time and effort. ${ }^{1}$ Care is integral to the health, wellbeing and survival of the society and economy. However, its benefits are often not recognized, and its responsibilities and associated costs continue to disproportionately fall on women, who spend two to 10 times more time on unpaid care work than men. ${ }^{2}$

Recognizing women's heavy and unequal contributions to care work as a key challenge to their participation in economic, political and social life and overall wellbeing, Oxfam launched a three-year initiative, WE-Care, in 2014 (now in its second phase). It works to build evidence on unpaid care, innovate on interventions, and influence policy and practice to address care as part of women's empowerment through support to programme teams in 10 countries. $^{3}$ In doing so, it aims to enhance women's empowerment by bringing about the following changes in the care economy: ${ }^{4}$

- Increase the recognition and value of unpaid care work at policy, community and household level;

- Reduce the long hours and heavy workload that falls on poor families, for example by providing better access to care-related services (health, child and eldercare) and infrastructure (water, electricity and transport), and introducing time- and labour-saving technology and services;

- Redistribute care responsibilities more equitably between men and women, and boys and girls, but also between the households, the state, employers and civil society;

- Enhance the representation of care providers in decision-making at different levels.

Apart from national-level time use surveys, which most developing countries have only conducted rarely, there is little information on care work and the allocation of time between paid and unpaid work and leisure. Therefore, research constitutes a key component of Oxfam's WE-Care initiative. Context-specific evidence generated through the research is intended to inform the design of programme interventions, as well as inform and influence policy processes. For this purpose, two practical and low-cost research tools have been developed:

- Rapid Care Analysis is a participatory methodology consisting of a set of exercises designed for a quick analysis of care relations in the communities. Through focus group discussions, it aims to assess the gendered distribution of care responsibilities, estimate the time men and women spend on care work, explore social norms relating to unpaid care, and identify problematic care activities and options to reduce and redistribute care work. ${ }^{5}$ This methodology was drawn upon to design the care module in the effectiveness review, as well as the qualitative follow-up study.

- The Household Care Survey is designed to generate data on time use and (dis)enabling conditions for women. It is implemented before and after interventions, to identify potential pathways for positive change. ${ }^{6}$ 
A care module (a shorter version of the Household Care Survey) was integrated into two of Oxfam's effectiveness reviews, and tested in Uganda and Ethiopia to evaluate the impact of different projects on unpaid care work and related aspects of gender relations. ${ }^{7}$ The results were then taken as the starting point for a follow-up study, using in-depth qualitative research methods to explain and expand upon the quantitative data. One of these projects, PGSLK, and its mixed-methods evaluation, is the focus of this report, which distils and reflects on the findings from the effectiveness review and the qualitative follow-up study.

As well as discussing the wider implications of its results for addressing care in women's empowerment (particularly in post-conflict settings in Uganda and beyond), this report also reflects critically on the process of the evaluation itself, and how this might be improved. It is hoped that this will stimulate discussion and debate, as well as help prepare the ground for further studies of this kind. 


\section{PROCESS: THE PROJECT IN UGANDA AND ITS EVALUATION}

The PGSLK project, funded by Oxfam Ireland, took three and a half years (2011-14) and was undertaken by Oxfam GB (OGB) in the Kotido and Kaabong districts of Karamoja in north-east Uganda. This region has suffered from chronic food shortages and high levels of poverty, exacerbated in recent decades by severe political insecurity and adverse environmental conditions, being prone to drought. Poor women in Karamoja are particularly disadvantaged due to a lack of access to and control over resources, exploitation, and harmful social norms. As such a series of Oxfam interventions has been implemented in this area to support women's livelihoods and promote their socio-economic empowerment and rights.

\section{Figure 1: Map of Kotido district}

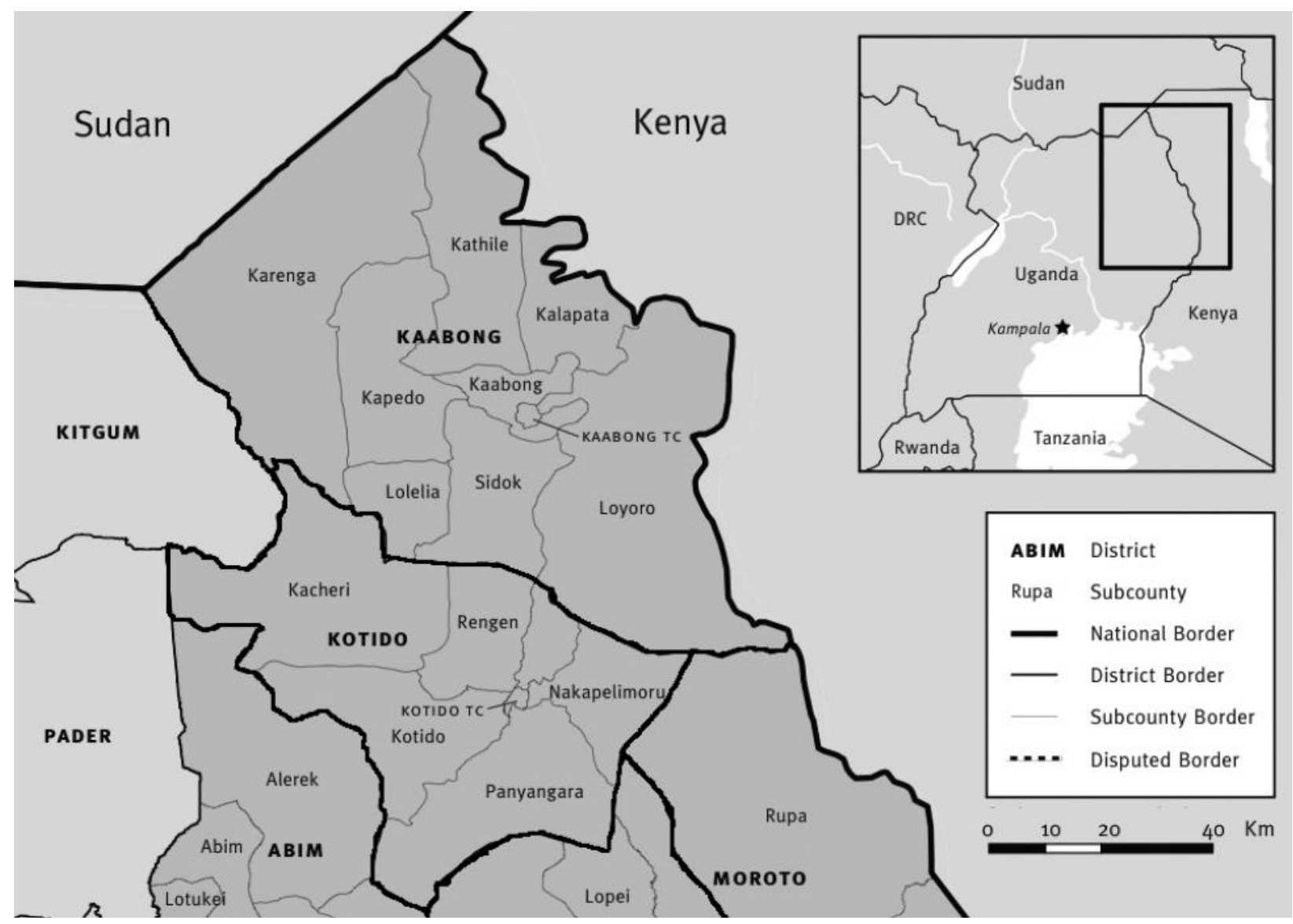

Source: adapted from Krätli $(2010)^{8}$

The PGSLK project had two specific objectives and work streams: women's economic empowerment through provision of support to women's income generation and livelihoods in Kotido using the GALS approach, and the ending or reduction of violence against women and girls in a number of sub-counties in both districts. The latter was implemented by two local partners: Karamoja Diocesan Development Services (KDDS) and the Dodoth Agropastoral Development Organization (DADO). The GALS work was the subject of a learning review undertaken in September $2013,{ }^{9}$ and both components were evaluated qualitatively in a final project report that was prepared by country staff in March 2014, after the project 
had ended. ${ }^{10}$ Neither project component focused specifically on unpaid care work, nor did these two evaluations.

\section{Box 1: Timeline}

- November 2011: start of the PGSLK project in north-east Uganda

- September 2013: GALS review

- March 2014: end of PGSLK project

- August-October 2014: effectiveness review research undertaken in Kotido district, published in December 2015

- June-July 2015: qualitative field research for follow-up study undertaken in Kotido. Consultant's report completed in September 2015

\section{The effectiveness review of the PGSLK project}

Under OGB's Global Performance Framework, the PGSLK project was later randomly selected for a quantitative evaluation of its impact on different aspects of women's empowerment. Research for the resulting effectiveness review was undertaken using a quasi-experimental impact evaluation design. ${ }^{11} \mathrm{At}$ the same time it was decided that the effectiveness review would provide a good opportunity for in-depth research of care-related issues, as part of Oxfam's WE-Care initiative. Questions about care and unpaid work were therefore added to the survey questionnaire, in a bespoke care module.

Fieldwork for the effectiveness review was conducted in Kotido district in August-October 2014. The questionnaire was administered to two intervention (treatment) groups: 185 randomly selected women's group members who had participated in GALS training, and 187 who had been exposed to the project's EVAWG component. A comparison (control) group of 380 women who had not taken part in the project was identified in Nakapelimoru sub-county. Analysis then focused on teasing out statistically significant differences between these contrasting groups, using propensity score matching and multivariable regression to reduce bias in the comparisons made between them.

The results of the effectiveness review were published in December 2015. ${ }^{12}$ They provided compelling evidence that the GALS component of the project was successful in enhancing women's empowerment and boosting their business activities and material wealth. In particular, women's participation in these activities was associated with higher levels of self-confidence in their economic role, more positive perceptions around their gender and property rights, as well as higher levels of access to savings and credit, more group participation, and increased involvement in group decision-making. However, the evaluation did not find evidence of improved decision-making power within the household or control over household assets. When looking at women participating in EVAWG activities, the evaluation did not find similar evidence of empowerment. However, it did find some evidence of women's improved knowledge of where to go and what support to seek when being subjected to violence.

Though not the principal focus of the effectiveness review, which was designed to evaluate the project against its theory of change, care and unpaid work was included as one of the five key dimensions of women's empowerment on which the project was assessed. The care module in the survey questionnaire collected information on time devoted to care activities within the previous 24 hours, and whether time spent on such activities had increased or decreased since 2010. It also included indicators on the redistribution of care responsibilities, attitudes towards and awareness of care work, and time for leisure and socializing. 
The evaluation found women's care responsibilities to be very high across both intervention and comparison groups, with women reporting 15 hours of care work per day on average. However, it did not find any statistically significant positive impact of project activities on any of the dimensions of care and unpaid work. Instead it found that women in the intervention group reported a lower number of hours devoted to leisure and socializing.

\section{Table 1: Key results of the effectiveness review (care and unpaid work highlighted)}

\begin{tabular}{|c|c|c|c|c|c|}
\hline \multicolumn{3}{|c|}{ WEE activities } & \multicolumn{2}{|c|}{ VAW activities } & \multirow[b]{2}{*}{ Comments } \\
\hline $\begin{array}{l}\text { Outcome } \\
\text { area }\end{array}$ & $\begin{array}{l}\text { Linked } \\
\text { to the } \\
\text { project } \\
\text { logic }\end{array}$ & $\begin{array}{l}\text { Evidence } \\
\text { of impact }\end{array}$ & $\begin{array}{l}\text { Linked } \\
\text { to the } \\
\text { project } \\
\text { logic }\end{array}$ & $\begin{array}{l}\text { Evidence } \\
\text { of impact }\end{array}$ & \\
\hline $\begin{array}{l}\text { Overall } \\
\text { measure of } \\
\text { women's } \\
\text { empowerment }\end{array}$ & Yes & Yes & Yes & No & $\begin{array}{l}\text { Women involved in project's WEE activities present } \\
\text { statistically significant higher levels of women's } \\
\text { empowerment overall. On the other hand, women } \\
\text { involved in project's VAW activities do not present } \\
\text { higher levels of women's empowerment. }\end{array}$ \\
\hline $\begin{array}{l}\text { Self- } \\
\text { perception, } \\
\text { personal } \\
\text { change and } \\
\text { opinions }\end{array}$ & Yes & Yes & No & No & $\begin{array}{l}\text { Women involved in WEE activities appear to have } \\
\text { changed their opinions on women's economic role, } \\
\text { gender rights, and property rights. }\end{array}$ \\
\hline $\begin{array}{l}\text { Personal } \\
\text { freedom and } \\
\text { violence }\end{array}$ & Yes & Not clear & Yes & Not clear & $\begin{array}{l}\text { Results on attitudes to gender-based violence are } \\
\text { unclear. The evaluation identified higher } \\
\text { acceptability of gender-based violence among the } \\
\text { group of women involved in VAW activities. } \\
\text { However, the literature suggests that these } \\
\text { estimates should be treated with caution as they } \\
\text { may reflect instead a greater willingness to discuss } \\
\text { the issue. Estimates suggest lower prevalence of } \\
\text { violence among women who participated in WEE } \\
\text { activities as well as among women who participated } \\
\text { in VAW activities; however, these differences are } \\
\text { not statistically significant. }\end{array}$ \\
\hline $\begin{array}{l}\text { Access and } \\
\text { control over } \\
\text { resources }\end{array}$ & Yes & Yes & No & No & $\begin{array}{l}\text { Women involved in WEE activities reported higher } \\
\text { levels of contribution of personal income to the } \\
\text { household; however, this is not reflected in higher } \\
\text { levels of asset ownership by the household. The } \\
\text { evaluation also found evidence that women } \\
\text { engaged in the project's WEE activities had higher } \\
\text { levels of access to savings and credit. }\end{array}$ \\
\hline $\begin{array}{l}\text { Decisions and } \\
\text { influence }\end{array}$ & Yes & No & No & No & $\begin{array}{l}\text { There is no evidence of improved decision-making } \\
\text { power within the household for either group of } \\
\text { project participants. Women involved in project's } \\
\text { WEE activities report lower levels of household } \\
\text { decision-making power than women in the } \\
\text { comparison group. }\end{array}$ \\
\hline $\begin{array}{l}\text { Support from } \\
\text { social network }\end{array}$ & Yes & Yes & No & Yes & $\begin{array}{l}\text { The evaluation found higher levels of group } \\
\text { participation associated with both groups of project } \\
\text { participants, and higher levels of support from the } \\
\text { different groups these women were involved with to } \\
\text { purcusown initiativo. }\end{array}$ \\
\hline $\begin{array}{c}\text { Care and } \\
\text { unpaid work }\end{array}$ & Yes & No & No & No & $\begin{array}{l}\text { Estimates suggest that women involved in project's } \\
\text { WEE activities are associated with a smaller amount } \\
\text { of time devoted to leisure, compared with women } \\
\text { not involved into project activities. }\end{array}$ \\
\hline $\begin{array}{c}\text { Household } \\
\text { wealth }\end{array}$ & Yes & Yes & No & No & $\begin{array}{l}\text { There is evidence that women involved in the } \\
\text { project's WEE activities appear to have greater } \\
\text { levels of household wealth compared with similar } \\
\text { women not involved into the project. }\end{array}$ \\
\hline $\begin{array}{l}\text { Involvement in } \\
\text { business } \\
\text { activities }\end{array}$ & Yes & Yes & No & No & $\begin{array}{l}\text { Women involved in the project's WEE activities } \\
\text { appear to be } 17 \text { percentage points more likely to be } \\
\text { participating in business activities than similar } \\
\text { women not involved in project activities. }\end{array}$ \\
\hline
\end{tabular}

Source: Lombardini \& Yoshikawa (2015) ${ }^{13}$

8 Transforming Care after Conflict: How gendered care relations are being redefined in northern Uganda 


\section{The follow-up study and its methodology}

A qualitative follow-up study was commissioned to deepen the findings of the effectiveness review, and provide a more comprehensive understanding of changing gender and care relations in Kotido, and how these have impacted upon and in turn been impacted by the PGSLK project. ${ }^{14}$ It addressed the following research questions:

1. How are gender relations and the care economy changing in different parts of Kotido district?

1.1 How have gender relations changed over time in different communities and households within them and what have been the causes of these changes? What is the situation now? Have these changes impacted on women's economic empowerment and unpaid care work and are they still affecting it? How and why?

1.2What implications does this have for gender inequality and women's political and economic empowerment at different levels?

2. What impact, if any, did these changes have on Oxfam's PGSLK project in Kotido district, and are they continuing to have an impact on the groups and communities involved?

3. What impacts on gender relations and care, if any, are attributable to the PGSLK project itself in Kotido district?

3.1 What, if any, impacts are attributable to the PGSLK project and what can be explained by other factors (e.g. other projects/interventions, systemic changes in gender relations and gendered distribution of work, particularly unpaid care work)?

3.2How can the impacts (and non-impacts) discerned in the PGSLK project effectiveness review (and its current analysis) be explained? ${ }^{15}$

In doing so, the study focused on the women's economic empowerment and GALS component of the PGLSK project, although reflections on the prevalence of VAWG were also included.

Fieldwork was conducted in Kotido district in June-July 2015 over a total period of 20 days. Data was collected in three different project communities in Kotido sub-county, where Oxfam had supported women's groups; and two comparison communities in Nakapelimoru sub-county, outside the intervention area.

The field research used the following qualitative methods to explore changes in gendered care relations and their implications for the PGSLK project:

- Literature review (of Oxfam WE-Care documents, PGSLK project and evaluation reports, and other sources relevant to understanding the project and its impacts, including findings from existing research in the project area);

- Thirty-one semi-structured interviews with men and women in intervention and comparison communities, to explore the gendered distribution of care responsibilities at family level, and also social norms and perceptions related to care work and factors contributing to changes in care relations;

- Nine focus group discussions with men and women separately, in intervention and comparison communities to discuss changing care relations in more depth, explore processes of social change in the region, and reflect on the prevalence of domestic violence in Kotido;

- Participant observation in four households in intervention and comparison communities, to capture additional aspects of care work; 
- Rapid Care Analysis conducted with members of one women's group, their husbands and other male family members, to complement data collected through other methods. ${ }^{16}$

\section{Findings of the follow-up study}

The following sections will present the key findings and reflections based on further analysis of the consultant's report. Where relevant, results from the effectiveness review and earlier evaluations are also taken into account.

\section{The gendered distribution of care work in Kotido}

To understand the gendered distribution of care work in Kotido, the follow-up study examined gender and labour relations in the area more broadly. The peoples of Karamoja, including the Jie of Kotido, have typically employed a dual livelihoods strategy, relying on a combination of semi-nomadic pastoralism and crop cultivation, adapted to the semi-arid conditions of north-eastern Uganda. ${ }^{17}$ This has translated into a traditional division of domestic groups between i) the villages where women, children and elderly people reside and farm, and where social and ritual activities take place, and ii) mobile livestock camps (kraals) inhabited mainly by adolescent and adult men, where livestock are herded and protected. As noted in earlier evaluations and analysed in depth in the follow-up study, this traditional spatial and economic division is also reflected in a gendered division of labour. While women have been primarily in charge of the garden and the home, men have been responsible for livestock and ensuring the security of their families. ${ }^{18}$

The follow-up study confirmed the findings of the effectiveness review regarding the long hours of care work undertaken by women in both intervention and comparison communities. It found that the provision of direct and indirect care in the village setting is primarily the responsibility of women. Women are in charge of cleaning and sweeping the house and homestead, fetching water and firewood, collecting greens, grinding, cooking and brewing, feeding and bathing children, and washing clothes and crockery; often performing several tasks simultaneously. These care activities are not limited to their own homes, but also include help given to other family members and friends.

\section{Box 2: An example of a woman's care work}

Nadon is married, but still based in her mother's home. The people she cares for on a daily basis are her three children, her husband, her parents and siblings. Her daily responsibilities include sweeping, fetching water, grinding, collecting greens and washing clothes. She checks on her parents in case they have fallen sick, takes them to the clinic and fetches bathing water for them. If her father or brother is in need of clothes or shoes, she buys them. Moreover, she spends about three days a week in her husband's home, helping the mother-in-law fetch water and assisting her in weeding. If a friend has given birth, she buys soap for her. Every month she visits her sister-in-law in [another village], bringing salt and helping her to weed, collect firewood or sell beer. Once a year she goes to see her friends who are living far away and gives them part of her harvest.

Source: Gärber (2015) ${ }^{19}$

By contrast, in the kraal, where women are absent, men have significant care responsibilities, including taking care of young herd boys, ensuring that they eat and bathe, and nursing them in case of sickness. 


\section{Networks of care}

In identifying who assists in care-related activities in the villages and kraals, the qualitative study revealed networks of care in both places; where daughters, sons, husbands, wives, other female relatives and women from the close community render support in different circumstances, with different factors influencing the likelihood and level of support provided. These networks are illustrated diagrammatically in Figures 2 and 3 below. In these figures, proximity to the centre represents greater levels of support provided, and the openings indicate exceptions to this.

\section{Figure 2: Networks of care in the village}

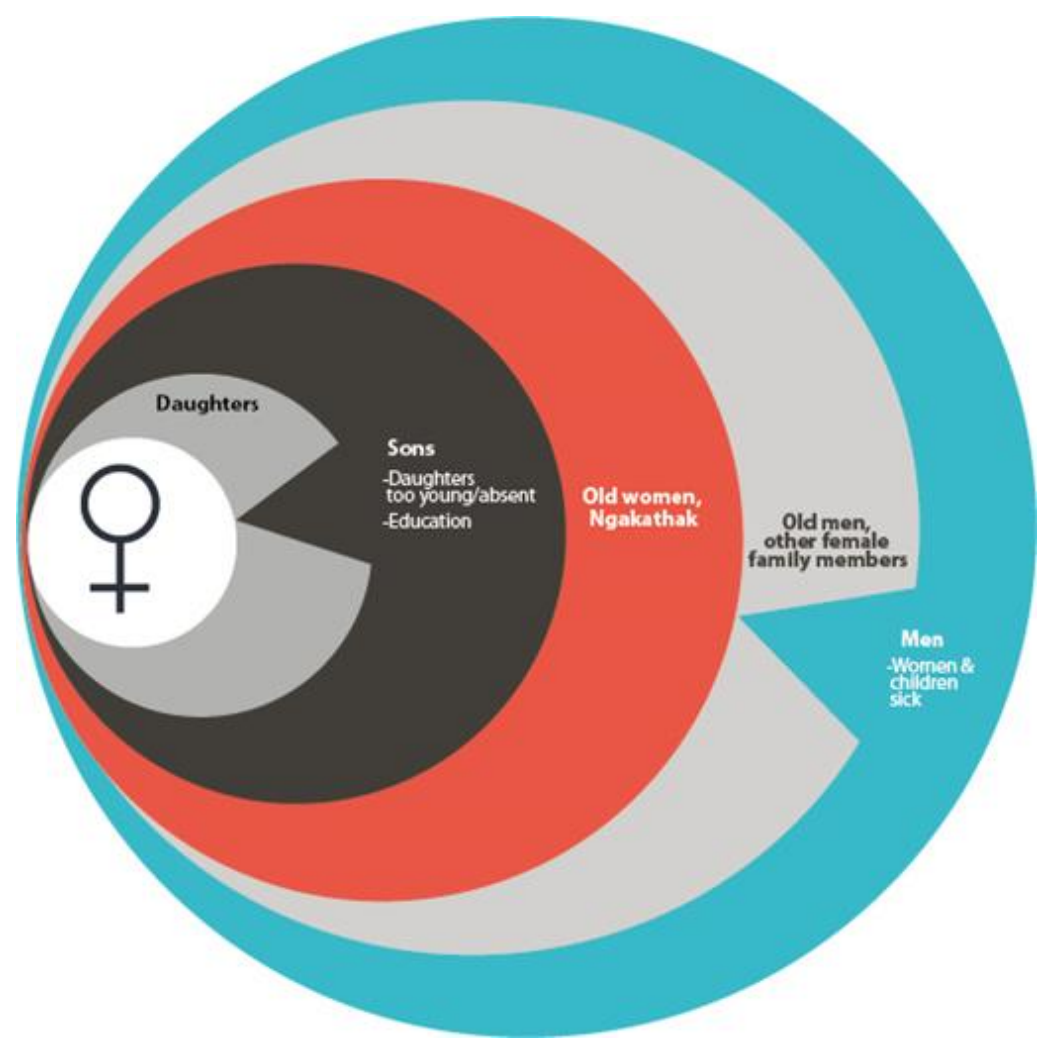

From an early age, daughters in the villages are expected to help their mothers in various domestic and childcare-related activities. During the Rapid Care Analysis, one woman participant declared: 'Whatever the mother does, the girl also does. ${ }^{20}$ Sons primarily help in livestock-keeping and cultivation, and less in domestic work. But where their sisters are too small or have left to live with their in-laws, they take on considerable care responsibilities. Another factor that influences sons' involvement in care work is education: at school, they are taught the importance of helping their parents. Old women also assist with care work, particularly looking after children while parents work in the garden.

In the absence of children, or when they are too small, it is common practice for families in Kotido to ask their relatives or neighbours to send one of their daughters to live with and assist women in childcare and domestic work in return for food, a share of the harvest, or financial and other assistance. These girls, called ngakathak (singular nyakathan), are often quite young and sometimes stay with their host family for several years. Families living with a nyakathan sometimes send their own daughters to another family for the same purpose, an indication of the importance of creating and maintaining networks of care. 
If there are no ngakathak in the home or if more labour is needed, women are free to call on other female family members for support with care work. Although care work is usually the domain of female family and community members, men play an important role when their wives or children are sick, by managing the redistribution of care work and instructing other children (including ngakathak) on what work to do. Old men are said to occasionally assist in care work itself; particularly cooking, childcare and by providing moral support.

\section{Figure 3: Networks of care in the kraal}

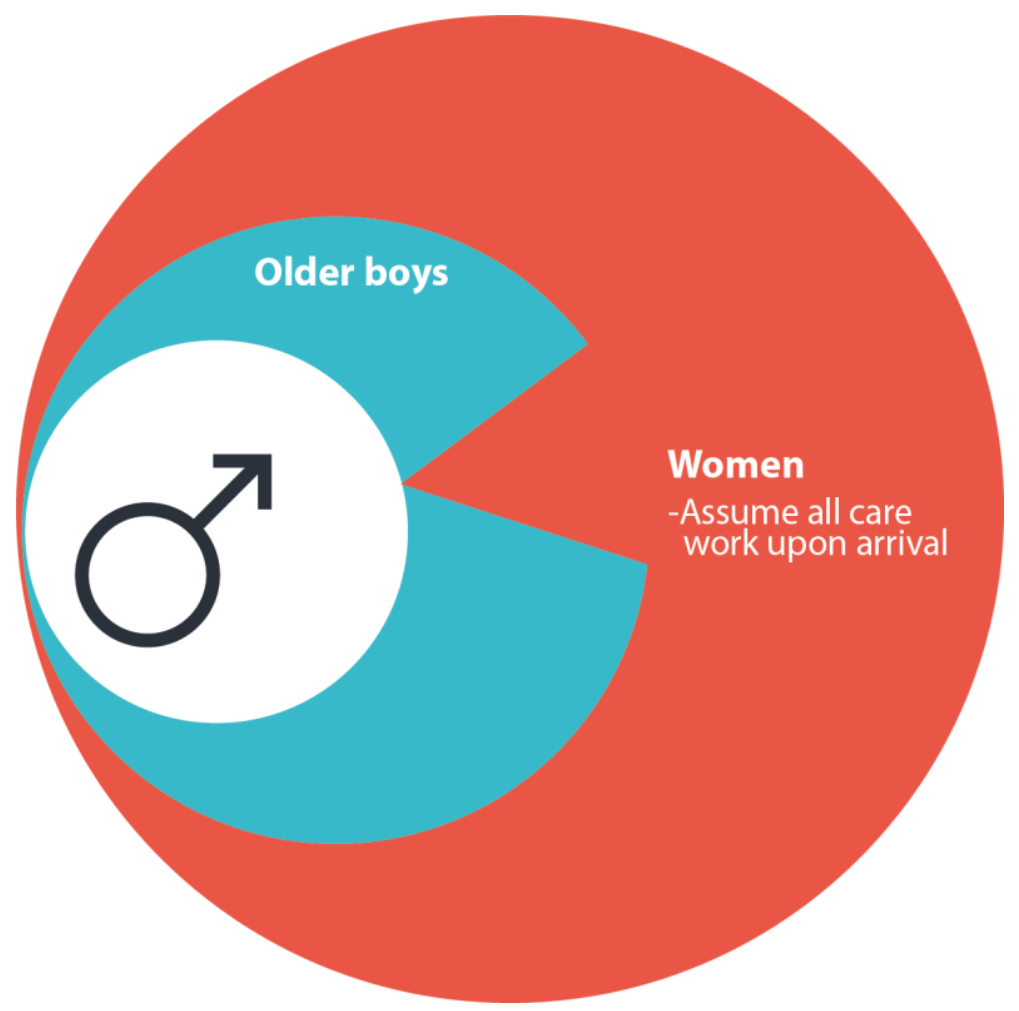

In the kraal, in the absence of women, men hold significant care responsibilities, particularly when herdboys sent to the kraal are young and require care and attention. This includes bathing, providing them with food, and taking care of them if they are ill. Older boys are expected to support adult herders in care work, including fetching water and looking after younger herd boys. Men's care responsibilities, however, cease when their wives and daughters arrive in the kraal during the dry season, and take over care work, including fetching water and firewood, and cooking.

\section{Factors influencing the gendered distribution of care work}

The follow-up study found that in both intervention and comparison communities, inequality in care responsibilities between men and women is primarily driven by cultural practice, social norms and unequal power relations.

When asked about the gendered division of work, men and women both said that care work is women's work, it 'is supposed to be for' and 'meant for' women, while men are seen as the main providers in charge of livestock, indicating the strong gendered social norms underpinning this division. ${ }^{21}$ Respondents mentioned that one of the reasons for this was women being biologically different from men; they can bend, have different hands and necks and hence can perform certain care activities such as grinding, 
cleaning the house and carrying water, which men allegedly cannot. It was also said that these differences are God-given and hence these traditional roles are also those dictated by religion.

\section{Box 3: Some statements by men about gendered capacities for work}

Men cannot 'bend' and are therefore unable to perform certain care activities such as grinding or cleaning the house: 'For men, kneeling like a woman is a big problem.'

Women carry firewood on their heads because 'women's necks are different from men's necks'.

'When a woman is born [God] gives her hands, different from [men's]; fingers, different from [men's]. All her body parts are different and even her work is different. In a way that she grows up knowing her work; that "this is meant for me". But it is not [me] who tells [the] wife that this is [her] work, no.'

Source: Gärber (2015) 22

The belief that this is appropriate and typical is also reflected in the social sanctions women and men said they face if they don't behave in accordance with their predefined roles. Men who involved themselves in 'women's work' would receive social ridicule from both men and women in their community, as well as their wives, who may feel insulted or ashamed. It was also stated that a woman who refuses to do her work may face divorce or domestic violence.

\section{Box 4: Reinforcing gendered norms with social ridicule and physical violence}

'You are stupid! Why do you do what is meant for a woman? Do you want to be like a woman?'

'Why do you make your husband cook? Can't you cook? Don't you have daughters or your children to cook? Why do you have to leave your husband to cook?'

'They consider this work to be for woman. If you make the mistake of telling a man, "Please sweep here", you end up being beaten: "Am I a woman, am I a woman?"'

Source: Gärber $(2015)^{23}$

Social and gender norms are also critically shaped by and in turn perpetuate unequal power relations, whereby men are considered to be superior to women. This was expressed in terms of men having the right to their wife's labour, established with the payment of bridewealth (traditionally mainly cattle). As explained by two women:

'[Men] are thinking, "Once you marry a woman [...] she has to do everything for you." So you find a man seated because he has paid dowry [bridewealth] and he has paid for all the children - "She has to do a lot of work, she has to do all the work and she has to produce for me because I have paid for her."'24

A good wife is defined as a woman listening to the husband and responding to his requests. These unequal power relations are also expressed through inequalities in economic responsibilities and rights, where men control the means of economic production and social reproduction more generally. The gender and livelihoods analysis that informed the design of the PGSLK project found that most of the key resources, and especially land and livestock, were owned and controlled by men. ${ }^{25}$

There are also large variations in care workloads between women based on differences in their age and status in relation to the structure and composition of their households. Their responsibilities vary, in other words, according to both life-cycle stage and the position of their households in the 
developmental cycle of domestic groups. Women reported their care responsibilities increased upon marriage and their move to the husband's home, as care work was no longer shared with their mother and sisters. However, they decreased with age and, temporarily, during pregnancy and the days after delivery. Similarly, men's roles and attitudes towards care work change as they pass through different stages of life.

The overall workload a woman is faced with and the types of work she is engaged in also vary considerably according to season. During rainy season, women find it particularly difficult to meet care responsibilities, spending most of their time and strength cultivating, weeding and harvesting. Other seasonal factors determining women's workload include male migration to kraals and school holidays.

\section{Changes in gender and care relations}

Are gender relations and the care economy changing in Kotido district? If so, how have they impacted and in turn been impacted upon by the PGSLK project?

The follow-up study found that gendered labour relations are going through a profound transformation in Kotido. In both sub-counties in which research was undertaken (Kotido and Nakapelimoru), men are increasingly taking on and actively engaging in agricultural work, such as hoeing and weeding, which are traditionally considered female tasks. Gendered responsibilities for care also seem to be gradually changing. The increased engagement of men in household care activities was reported, particularly in intervention but also in comparison communities. This included their participation in domestic work, childcare, and the nursing of family members who are unwell. However, whereas crop cultivation is increasingly said to be a man's work as well as a women's, care work continues to be viewed as an essentially female domain that men can participate in, but are not required to involve themselves in.

\section{Box 5: Changing gendered labour and care relations}

'In those days men used to concentrate only on [...] livestock, going to the kraal, taking care of the animals. Now, people share work. Because in those days a man could not start sweeping the home, even go to the garden, a man used not to go. But nowadays a man can even handle a hoe to go to the garden, a man can even handle the broom to sweep the compound.'

'When you come back home you find that your wife has just arrived from the garden, the wife is tired, [...] she is struggling to cook. But for you a man, you just go and lie and wait for food. Even if you see the baby cry, you cannot help; no helping. You tell them, "Can you handle the baby? The baby is crying!" As the woman is there [struggling], washing the plates, washing saucepans, grinding. You, you are just lying. [...] Nowadays it is a different thing. [...] These days, you see that the other side is [suffering], you go and help.'

Source: Gärber $(2015)^{26}$

A critical observation of the follow-up study was that these changes in gender and care relations were not being driven by the PGSLK project, but by a complex interplay of different factors that was not captured by the effectiveness review. 


\section{Social and economic transformation ${ }^{27}$}

The changes outlined above can only be understood in the context of social and economic events in Kotido and the wider region. For decades, Karamoja has been the scene of violent conflict that mostly found its expression in the form of armed cattle raiding. This became increasingly deadly after the late 1970s, with the rapid proliferation of armed weapons in the region. Between 1983 and 1994 the Karamojong experienced violence of dimensions unmatched in their remembered history. Following government-led disarmament exercises, relative peace was eventually achieved only about seven years ago, prompting a profound social transformation. After decades of violent conflict and a significant reduction in local livestock populations, many families in Kotido have shifted away from pastoralism as their primary source of livelihood, and started to put increasing emphasis on crop agriculture. This development, actively encouraged by government and other development actors, has seen the progressive acquisition of former grazing lands for crop production.

This development has had profound impacts on gender relations. While agriculture, the traditionally female livelihood domain, has gained considerable significance in recent years, livestock herding and raiding, traditionally male activities, have dramatically declined in importance. With their cows and guns lost, men can no longer rely on their former livelihood strategies to fulfil their societal roles, namely to protect and provide for their families. They have also been unable to pay the bridewealth in cattle that traditionally entitled them to their wives' labour, and control over household resources. Moreover, men suddenly found themselves in the villages and no longer in the bush, where they used to spend most of their time, herding cattle and raiding. The resulting crisis of masculinity has forced men to redefine their roles in society and position in relation to women, and identify new ways of survival. Many have therefore started to engage in cultivation and a variety of off-farm activities, taking up casual labour, joining 'food for work' programmes, digging latrines, making bricks, and planting trees, and to a certain extent, supporting their wives in care work.

Chronic insecurity during the conflict years led to a concentration of settlement and dependence on food relief. The advent of peace has prompted the rapid establishment of new settlements across Kotido, as men have sought to explore new livelihood opportunities and open up farms on grazing lands that had been abandoned. Although the long-term effects of this on gender and care relations remain to be seen, interview data suggest that the resulting split of households between villages and new settlements may add to women's care work in both locations, as women are required to commute between the two locations and are away from networks of support.

\section{Development interventions by Oxfam and others}

The follow-up study found that interacting with the systemic social changes taking place, development interventions were also positively influencing changes in gender and care relations. In intervention communities, these changes were often attributed to Oxfam's PGSLK project and in particular the GALS training involving both wives and husbands. Referred to as 'Oxfam's teachings', this was often seen as a key factor in shifting men's and women's perceptions of work from being gender-specific towards the idea of 'shared work'. Other changes attributed to the GALS training were an increase in men's support to women in care work, couples listening to each other, and taking decisions and engaging in business together. 


\section{Box 6: Impact of the PGSLK project on care relations}

'[Things have improved] since the office brought the teachings. Men used to be big-headed, they never wanted work, but nowadays when [I go] maybe to the garden, the man does everything [at] home, even cooking, preparing breakfast, sweeping, washing, [serving you tea in the garden].'

'Men did not think, they [thought] that this work is specific for a woman [...] They were ignorant of what was supposed to be done, what was supposed to be shared, that it really made them believe that that work is specific for a woman. [...] As they started the group [...] they gave [us] some teachings that made [us] realize that a work of a woman is not there. Work for a man is not there. It is not specific, a man or a woman. But work is always supposed to be shared between a man and a woman.'

'The teachings of Oxfam are what helped [us]. They told [us] [...] that each woman is supposed to come with her husband. So [we came] together and men also listened [...] [Before] work for men was only rearing cattle and sitting under the tree. Only. Even if he does not rear any cattle, his work is only to lie under a tree, till sunset.'

Source: Gärber (2015) ${ }^{28}$

Men were motivated to join and learn from the training when they saw the economic benefits to women of participating in women's groups. Domestic violence and alcohol consumption were also reported to have reduced as a result of the training. However, this is a gradual shift, as some men still find it difficult to join the groups because it runs counter to social expectations about their behaviour. Some of those men who did attend group meetings and GALS training struggled to incorporate the teachings into their daily lives, especially those relating to care work, because they were judged negatively by other men.

The PGSLK project was also acknowledged for improving women's access to cash and credit, confirming the findings of the effectiveness review around women's access to resources.

In comparison communities, government and other NGO interventions were frequently mentioned as major drivers of change in increasing men's engagement in agricultural work, and (to the extent that this did increase) their contribution to care work.

\section{Box 7: Impact of other interventions on care relations}

'The NGOs [...] made [us] start to help [our] wives [...] [We realized that] whatever [we] had been doing like lying under trees [was] just making [our] own home lag behind [...] That is how work is now being shared, in a way that you share ideas. Like maybe a child has fallen sick, a man tells a lady.'

'[Men] have ever been in the bush, they do not know [domestic work] [...] Now they are learning because Museveni came in and tried educating them. That is how they are now trying. They tried things like going to the garden. But they are just starting [...] Homework has not started but the garden has started.'

Source: Gärber (2015) $)^{29}$ 


\section{Other drivers of change}

Men's increased engagement in agricultural and care work was also attributed to their education, religious teachings, exposure to urban life and sensitization by local politicians. For instance, a man who had completed his formal education and engaged in housework for many years explained how he had learned of the benefits of shared work through reading books and newspapers and listening to the radio. School education was reported to have a positive impact on increasing boys' participation in domestic work. Exposure to urban contexts, where men engage in paid domestic work, was also said to have a positive influence on gender and care relations, as were the teachings of the Bible.

\section{What can and cannot be explained?}

How can these findings help explain the impacts (and non-impacts) discerned in the PGSLK project effectiveness review?

- The follow-up study revealed that gender and care relations are being transformed across Kotido. These changes can be attributed to a number of interacting factors, including the wide-ranging effects of conflict and the ensuing peace, the impacts of different development interventions, the increasing importance of education, and the influence of modern life and religion. The PGSLK project is only one factor among many, and this may explain why the effectiveness review did not find statistically significant differences between project intervention and comparison communities in the levels, distribution and attitudes towards care work, despite finding positive changes in these dimensions in intervention communities over time.

- The follow-up study found that the PGSLK project did have an impact on changing men's attitudes towards care work and care relations, but only in combination with the wider social and economic changes which were not captured by the effectiveness review. Men and women alike stated that if men had not lost their cattle, been disarmed and moved back to the villages, it is unlikely that they would have engaged with the GALS training or accepted any of its teachings. Social and economic transformation in Kotido provided a fertile ground for development interventions and different kinds of education and sensitization, in both intervention and comparison communities.

- Although men's attitudes to and involvement in care work are gradually changing across Kotido, deeper changes are taking place in the gendered definition and distribution of agricultural work, which is also traditionally considered to be 'women's work'. This was not considered in the effectiveness review, which only covered gendered distributions in care work. But these changes have important implications for care work because they have begun to shift social norms around what is considered to be women's versus men's work, as well as changing intra-household power relations. These also underpin the unequal distribution of care work.

- An unexplained finding from the effectiveness review was that women in the intervention group reported a significantly lower number of hours (2.5) devoted to leisure activities, compared with women in the comparison sample. This may be an effect of their participation in group income generation and other activities, and not necessarily negative. Women in groups reported taking up hygiene and sanitation-related activities, due to greater awareness through community sensitization, and more time being available owing to male support and infrastructure provided by Oxfam. 


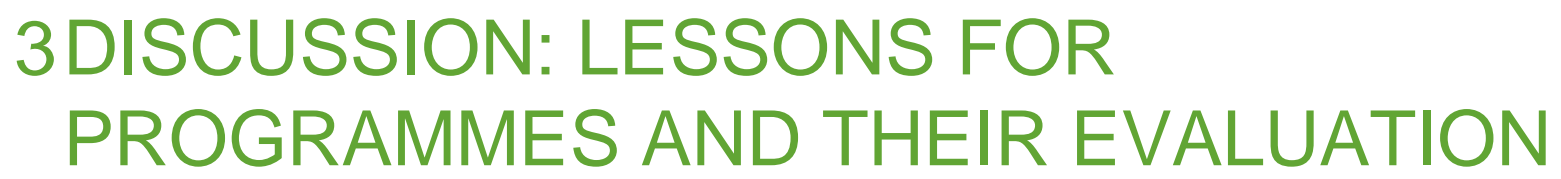

It should be emphasized that these findings have been distilled from the interviews and the report of the qualitative follow-up study, which provide a lot more detail than can be given in a short overview. ${ }^{30}$ Nonetheless, we believe that these are important findings and that a number of lessons should be drawn from them. These are discussed below, along with some of the methodological implications of this study for future evaluations.

\section{Lessons for women's empowerment programmes}

The follow-up study, in contrast to the effectiveness review, revealed that the PGSLK project did contribute to changing gender and care relations in Kotido, but only in combination with wider social and economic changes that are redefining gender roles in both intervention and comparison communities. The most significant of these changes have been those associated with the end of armed conflict in Karamoja and the development of new livelihood strategies by men. This has seen them take up agricultural work and other activities that were previously considered to be mainly the preserve of women. Development interventions by other NGOs and the state have also played a part in fostering the redefinition of men's roles, as have other influences, including church teachings and greater awareness of contemporary urban lifestyles.

The evaluation of the PGSLK project and the follow-up study in particular offer a few important lessons for the design and assessment of women's empowerment programmes:

- An analysis of gender and care relations in their wider social, political and economic context is critical to understanding the social practices, norms, attitudes and behaviours that drive the gendered distribution of labour and care work. Care work cannot be analysed adequately in isolation from gender and labour relations more generally, nor can significant changes in these be identified in full without analysing social and economic trends in the wider community and society at large.

- For programmes that want to address care as part of their theory of change, understanding the wider context and networks of care is essential to identifying key entry points for influencing the redistribution of care work. In Kotido, men's return to the villages and increasing involvement in agricultural work provided a key opportunity for project interventions, as did other changes such as the education and sensitization of both men and boys in different institutional settings.

- For the same reason, it is important to understand how and why care responsibilities change in relation to men's and women's lifecycles, and the developmental cycle of their households and extended domestic groups over time. Likewise, it is also important to know what impact different seasonal factors, such as agricultural and school calendars, have upon care work. A further consequence of this is that it can be misleading to compare the results of different snapshot surveys of care, when seasonality and similar variables are not taken into account.

- Identifying and tackling entrenched social and gender norms that perpetuate the inequalities of care as well as drive violence against women is critical to increasing men's involvement in care work. The GALS training in Kotido sought to shift key gender norms that defined the nature of men's work and decreed that a woman's labour is the property of her husband. As we have seen, a range of factors are contributing to the redefinition of these norms, and there remains considerable scope for further change. 
- The analysis of gender norms and related practices can also help programme planners identify where opportunities for market activities and income generation lie, what needs to change to allow women to engage in them, and how development interventions can be designed to facilitate this. The gender and livelihoods analysis which was undertaken to inform the PGSLK project, for example, showed that it is essential for men to take on care responsibilities, if women are to have the time required to invest in other economic activities. ${ }^{31}$ This in turn requires a shift in the social norms around what is considered to be men's and women's work.

- The follow-up study also suggests important lessons for humanitarian and resilience-building programmes. In situations of adversity, where patterns of settlement and mobility are changing and livelihoods are being lost as a result of conflict and/or the impacts of climate change, it is likely that gender relations and roles are being redefined. Again, this offers opportunities for project intervention. If they are not doing so already, humanitarian and resilience-building programmes should consider the gendered impacts of the crises they are addressing, and adopt gender-integrated approaches to programming that take account of care work and the potential for shifting norms.

\section{Lessons for research and evaluation}

The quantitative impact evaluation of the PGSLK project and its qualitative follow-up comprise, in effect, a mixed-methods evaluation. The follow-up study, like others in this series, has highlighted the value of combining quantitative and qualitative approaches in impact evaluation, so that they inform each other, provide unique insights, and enhance collective explanatory power. ${ }^{32}$ By examining one dimension of women's empowerment within the wider social and economic context in which it is embedded, the follow-up study uncovered a host of factors underlying the findings of the effectiveness review. Furthermore, by using different methods (semi-structured interviews, focus group discussions, participant observation and Rapid Care Analysis), the follow-up study effectively triangulated data to both crossvalidate findings and capture different dimensions of the same phenomena.

\section{How can the process be improved?}

There are, however, a number of ways in which this mixed-methods evaluation could have been improved. They can be summarized as follows:

- By better integrating and sequencing different evaluations. Although care work was included in the effectiveness review as one of a number of dimensions against which the PGSLK project was evaluated, the final report was not informed by the gender analysis and evaluations conducted earlier, which could have contextualized the evaluation findings. These earlier analyses should have been taken into account in survey design and the interpretation of results. Similarly, the follow-up study was undertaken before the complete findings of the effectiveness review were published, and so was not designed to address all of the questions that arose from the quantitative survey. Evaluations need to be better coordinated and purposefully designed to build on the findings of each other, to ensure effectiveness and cost efficiency.

- By integrating quantitative and qualitative methods in effectiveness reviews so that they inform each other, enhance explanatory power, and reduce costs and other resource requirements. In the case of the PGSLK review, a better-integrated process might have made the impact evaluation team aware of the potential for contamination when they were selecting and comparing the intervention and comparison groups. Exposure of the latter to development interventions that seem to have had similar effects to Oxfam's suggests that it was not a valid group for comparison. Whether or not one could be found is another matter, reflecting a common challenge for evaluation and the attribution of impacts in intervention-rich environments. 
- By including social norms in statistical measures and indices for women's empowerment. Programmes that aim to change behaviours are also often explicitly (as part of their theory of change) or implicitly seeking to shift the social norms which underpin them. This is particularly the case in women's empowerment programmes, where research has shown that challenging problematic social norms is one of the most effective ways to tackle harmful practices. Hence it is important for OGB to include measures related to social norms as a part of its Women's Empowerment Index Framework. ${ }^{33}$

- By fully integrating questions about unpaid work and care into research and evaluation protocols. The care module developed for use in the PGSLK project effectiveness review was abridged by the survey consultant in the field, because he did not see the immediate relevance of these questions to the evaluation of the project's theory of change. The significance of the care module should have been properly explained in advance. This mistake might not have been made if care issues had been explicitly referenced in the project's theory of change.

- By improving and expanding the existing list of questions about care work, and ensuring that they are embedded in a broader framework that captures patterns of variation and other relevant informant about gender relations and how they are changing. The findings of the followup study suggest some of the ways in which this might be done. By only considering gendered distributions of care work, the effectiveness review missed the more significant changes that are taking place in the gendered definition and distribution of agricultural labour; changes that are evidently shifting social norms around men's work. The care module also missed other important variables that are discussed in this report, including the role that seasonality plays in determining distributions of care work. 


\section{CONCLUSION}

The most important lesson that can be drawn from this evaluation of the PGSLK project in Kotido is that care relations do not exist in a vacuum, and should not be treated or researched as such. The follow-up study showed that although the GALS component of the project had some positive impacts on men's attitudes towards care work and its gendered distribution, it only did so in combination with wider social and economic changes associated with the end of armed conflict in Karamoja and the development of new livelihood strategies that have redefined men's gender roles. To the extent that the gendered norms and practices of care are changing, they are part of a much broader process of transformation.

These changes were taking place across Kotido and provided a fertile ground for Oxfam and other agencies' initiatives. This underlines the importance of understanding the wider social, political and economic context in which gendered labour relations are continuously negotiated and livelihoods created, and the potential for interventions to take advantage of and sustain positive changes where these are occurring. This is especially pertinent in situations of adversity, where a loss of livelihoods and shifting patterns of mobility due to conflict or climate change may lead to gender norms being redefined, at least temporarily. In such cases, well-designed project interventions can play a critical role in ensuring that such changes endure and become truly transformative.

\section{ACKNOWLEDGEMENTS}

This report was written by Anam Parvez Butt (Quantitative Gender Justice Researcher, OGB) and Martin Walsh (Senior Researcher, OGB), based on the qualitative field research undertaken by Barbara Gärber (PhD candidate, University of Vienna).

Special thanks are due to everyone named in Barbara's consultancy report. Research was undertaken as part of an ongoing collaboration between the Research and Programme Quality teams in OGB, and we are especially grateful to Joel Dengel in Kotido and other Oxfam staff in Uganda for their assistance. These include: Patience Akumu, Rose Atim, Joselyn Bigirwa, Joel Dengel, Peter Kamalingin, Harriet Mbabazi, Charity Namara, Jane Ocaya-Irama and Jonathan Ochom. We are also grateful to many other past and present colleagues, including Imogen Davies, Irene Guijt, Claire Hutchings, Thalia Kidder, Simone Lombardini, Franziska Mager, Miranda Morgan, Jane Remme, Lucia Rost, and Kanako Yoshikawa. 
1 D. Elson. (2000). Progress of the World's Women. UNIFEM Biennial Report, United Nations Development Fund for Women.

2 G. Ferrant, L.M. Pesando and K. Nowacka. (2014). Unpaid Care Work: The Missing Link in Analysis of Gender Gaps in Labour Outcomes. Issues Paper, OECD Development Centre.

3 Countries include Colombia, Ethiopia, Honduras, Malawi, the Philippines, Uganda and Zimbabwe. Components of the initiative are being implemented in Bangladesh, Tajikistan and Zambia.

4 L. Karimli, E. Samman, L. Rost and T. Kidder. (2016). Factors and Norms Influencing Unpaid Care Work: Household survey evidence from five rural communities in Colombia, Ethiopia, the Philippines, Uganda and Zimbabwe. Oxfam evaluation report. Retrieved November 2017 from https://policypractice.oxfam.org.uk/publications/factors-and-norms-influencing-unpaid-care-work-household-surveyevidence-from-f-620145

5 J. Remme, T. Kidder and M. Michalopoulou. (2015). Oxfam's WE-Care Initiative: An Overview. Oxfam. Retrieved November 2017 from https://policy-practice.oxfam.org.uk/publications/oxfams-we-careinitiative-an-overview-555515.

6 Ibid.

7 The household care survey has since been revised to collect information about household assets, the value of unpaid care work, and children's time use - and to understand better factors associated with problematic levels of unpaid care including social norms, household decision making and genderbased violence.

8 S. Krätli. (2010). Karamoja with the rest of 'the rest of Uganda'. Nomadic Peoples, 14(2), 3-23, p. 12, Figure 2.

9 J. Kasande. (2013). Gender Action Learning Systems (GALS): Assessing Gender Changes and Peer Learning in Kotido Sub-County, Kotido District. Report to Oxfam GB.

10 Oxfam GB. (2014). Piloting Gender Sensitive Livelihoods in Karamoja: Final Project Report.

11 For an introduction to the effectiveness reviews and further information on their methodology and the reviews completed to date, see http://policy-practice.oxfam.org.uk/our-work/methodsapproaches/project-effectiveness-reviews. (This and other links cited in this note were last retrieved in July 2017). See also:

K. Hughes and C. Hutchings. (2011). Can we obtain the required rigour without randomization? Oxfam GB's non-experimental Global Performance Framework. Working Paper 13, International Initiative for Impact Evaluation. http://www.3ieimpact.org/media/filer_public/2012/05/07/Working_Paper_13.pdf

C. Hutchings. (2013). When we (rigorously) measure effectiveness, do we want accountability or learning? Update and dilemmas from an Oxfam experiment. Oxfam blog.

http://oxfamblogs.org/fp2p/when-we-rigorously-measure-effectiveness-do-we-want-accountability-orlearning-update-and-dilemmas-from-an-oxfam-experiment/

D. Bishop and K. Bowman. (2014). Still learning: a critical reflection on three years of measuring women's empowerment in Oxfam. Gender \& Development, 22(2), 253-269. http://www.tandfonline.com/doi/pdf/10.1080/13552074.2014.920993

C. Hutchings. (2014). Balancing accountability and learning: a review of Oxfam GB's global performance framework. Journal of Development Effectiveness, 6(4), 425-435. http://www.tandfonline.com/doi/pdf/10.1080/19439342.2014.971552.

12 S. Lombardini and K. Yoshikawa. (2015). Women's Empowerment in Uganda: Impact Evaluation of the Project 'Piloting Gender Sensitive Livelihoods in Karamoja'. Oxfam effectiveness review. https://policy-practice.oxfam.org.uk/publications/womens-empowerment-in-uganda-impact-evaluationof-the-project-piloting-gender-s-592575

13 S. Lombardini and K. Yoshikawa. (2015). Women's Empowerment in Uganda. p.6, Table 1.

14 B. Gärber. (2015). Women's Economic Empowerment and Care Work: Follow-up to the effectiveness review of Piloting Gender Sensitive Livelihoods in Karamoja (Uganda). Report to Oxfam GB. 
15 M. Walsh. (2015). Women's Economic Empowerment and Care Work: Follow-up to the effectiveness review of Piloting Gender Sensitive Livelihoods in Karamoja (Uganda). Terms of Reference for Research, Oxfam GB.

16 Gärber. (2015). Women's Economic Empowerment and Care Work. Annex 1: Study Methodology, pp.47-55.

17 Karamoja region is home to about 1.2 million people who speak closely related Eastern Nilotic languages and are commonly referred to as 'the Karamojong'. The Karamojong, however, do not represent a unified political entity, but consist of a cluster of different pastoralist groups. The three main ethnic groups in north-eastern Uganda are the Jie, the Dodoth and the Karamojong proper. The majority of the inhabitants of Kotido district are Jie. See Gärber. (2015). Women's Economic

Empowerment and Care Work. pp.1, 5, and references therein. The classic anthropological study is P. Gulliver. (1955). The Family Herds. A Study of Two Pastoral Tribes in East Africa: the Jie and the Turkana. London: Routledge \& Kegan Paul.

18 It should be noted, however, that these divisions are not always so stark: women and men do tend to have roles to play, though clearly defined, in both domains.

19 Gärber. (2015). Women's Economic Empowerment and Care Work. p.11.

20 Gärber. (2015). Women's Economic Empowerment and Care Work. p.12.

21 Gärber. (2015). Women's Economic Empowerment and Care Work. p.14.

22 Gärber. (2015). Women's Economic Empowerment and Care Work. p.14.

23 Gärber. (2015). Women's Economic Empowerment and Care Work. pp.15, 233.

24 Gärber. (2015). Women's Economic Empowerment and Care Work. p.15.

25 M. Mugisha and M. Musirika. (2011). Gender and Livelihoods Analysis in Kotido Sub-county Kotido District, Karamoja Region. Quest for Development (QD) Consult Ltd., report to Oxfam GB, p.6.

26 Gärber. (2015). Women's Economic Empowerment and Care Work. p.24.

27 This section based on Gärber. (2015). Women's Economic Empowerment and Care Work. pp. 21-29.

28 Gärber. (2015). Women's Economic Empowerment and Care Work. p.29.

29 Gärber. (2015). Women's Economic Empowerment and Care Work. p.33.

30 Gärber. (2015). Women's Economic Empowerment and Care Work, including the detail in Annex III, 'Fieldnotes', pp.63-363.

31 Mugisha and Musirika. (2011). Gender and Livelihoods Analysis in Kotido.

32 See: M. Walsh and R. Fuentes-Nieva. (2014). Information Flows Faster than Water: How Livelihoods Were Saved in Pakistan's 2010 Floods. Oxfam. Retrieved November 2017 from https://policy-

practice.oxfam.org.uk/publications/information-flows-faster-than-water-how-livelihoods-were-saved-inpakistans-201-317457

M. Walsh. (2016). Using interpretive research to make quantitative evaluation more effective: Oxfam's experience in Pakistan and Zimbabwe.

S. Bell and P. Aggleton (eds.). Evaluation in Health and Social Development: Interpretive and Ethnographic Perspectives. pp.219-231. Abingdon and New York: Routledge.

M. Walsh and S. Mombeshora. (2017). Turning Water into Wellbeing: How an Irrigation Scheme Changed Lives in a Zimbabwean Dryland. Oxfam. Retrieved November 2017 from https://policypractice.oxfam.org.uk/publications/turning-water-into-wellbeing-how-an-irrigation-scheme-changedlives-in-a-zimbab-620346

$33 \mathrm{It}$ is important to note that the revised Household Care Survey does include questions related to social norms, but that these are not yet a part of the women's empowerment index framework that is used in our regular effectiveness reviews. 


\section{Oxfam Research Reports}

Oxfam Research Reports are written to share research results, to contribute to public debate and to invite feedback on development and humanitarian policy and practice. They do not necessarily reflect Oxfam policy positions. The views expressed are those of the author and not necessarily those of Oxfam.

For more information, or to comment on this report, email research@oxfam.org.uk

(c) Oxfam International December 2017

This publication is copyright but the text may be used free of charge for the purposes of advocacy, campaigning, education, and research, provided that the source is acknowledged in full. The copyright holder requests that all such use be registered with them for impact assessment purposes. For copying in any other circumstances, or for re-use in other publications, or for translation or adaptation, permission must be secured and a fee may be charged. Email policyandpractice@oxfam.org.uk

The information in this publication is correct at the time of going to press.

Published by Oxfam GB for Oxfam International under ISBN 978-1-78748-131-2 in December 2017. Oxfam GB, Oxfam House, John Smith Drive, Cowley, Oxford, OX4 2JY, UK. DOI: 10.21201/2017.1312

\section{OXFAM}

Oxfam is an international confederation of 20 organizations networked together in more than 90 countries, as part of a global movement for change, to build a future free from the injustice of poverty. Please write to any of the agencies for further information, or visit www.oxfam.org

Oxfam America (www.oxfamamerica.org)
Oxfam Australia (www.oxfam.org.au)
Oxfam-in-Belgium (www.oxfamsol.be)
Oxfam Brasil (www.oxfam.org.br)
Oxfam Canada (www.oxfam.ca)
Oxfam France (www.oxfamfrance.org)
Oxfam Germany (www.oxfam.de)
Oxfam GB (www.oxfam.org.uk)
Oxfam Hong Kong (www.oxfam.org.hk)
Oxfam IBIS (Denmark) (www.ibis-global.org)

Oxfam Australia (www.oxfam.org.au)

Oxfam-in-Belgium (www.oxfamsol.be)

Oxfam Brasil (www.oxfam.org.br)

Oxfam Canada (www.oxfam.ca)

Oxfam France (www.oxfamfrance.org)

Oxfam Germany (www.oxfam.de)

Oxfam GB (www.oxfam.org.uk)

Oxfam IBIS (Denmark) (www.ibis-global.org)

\author{
Oxfam India (www.oxfamindia.org) \\ Oxfam Intermón (Spain) (www.oxfamintermon.org) \\ Oxfam Ireland (www.oxfamireland.org) \\ Oxfam Italy (www.oxfamitalia.org) \\ Oxfam Japan (www.oxfam.jp) \\ Oxfam Mexico (www.oxfammexico.org) \\ Oxfam New Zealand (www.oxfam.org.nz) \\ Oxfam Novib (Netherlands) (www.oxfamnovib.nl) \\ Oxfam Québec (www.oxfam.qc.ca) \\ Oxfam South Africa (www.oxfam.org.za)
}

